\title{
A Meteorological and Social Comparison of the New England Blizzards of 1978 and 2013
}

\author{
DAVID A. CALL and KATELYN E. GROVE \\ Ball State University, Muncie, Indiana \\ PAUL J. KOCIN \\ NOAA/NWS/NCEP Weather Prediction Center, Riverdale, Maryland
}

(Manuscript received 7 July 2014; review completed 25 November 2014)

\begin{abstract}
The Northeast United States Blizzard of February 1978 was an intense snowstorm that deposited $>30 \mathrm{~cm}$ of snow on much of the northeastern United States and disrupted life for millions of residents. The disruption was perhaps greatest in and around Boston, where $>60 \mathrm{~cm}$ of snow fell on a busy Monday, stranding thousands of commuters. Severe coastal flooding also caused major damage. For many area residents, life did not return to normal until the following week.

In 2013, a meteorologically similar blizzard once again affected the northeastern United States. Like before Boston received $>60 \mathrm{~cm}$ of snow-disrupting business and routine. However, the disruption was much shorter in duration. Few people were stranded on roadways, children only missed a few days of school, and the airport closed for less than one day.

The authors of this paper examined meteorological data, newspapers, and other accounts and information about the two storms to determine why the societal impacts were so different. Weather forecasting has improved significantly in the $35 \mathrm{yr}$ separating the storms, and this is one very important factor. Similarly, the substantial preparations made by the public sector and individuals in response to the forecasts of the 2013 storm also contributed to the large differences in impact. In conclusion, whereas the blizzards of 1978 and 2013 were somewhat similar storms, preparatory actions made in response to forecasts caused the impacts of the 2013 storm to be much less disruptive and shorter in duration than for the 1978 storm.
\end{abstract}

\section{Introduction}

In early February 2013, news media outlets in New England and elsewhere reported ominous forecasts of an impending blizzard. As the storm drew closer, National Weather Service (NWS) meteorologists upgraded winter storm watches to blizzard watches, and finally issued blizzard warnings through much of the region for 8-9 February 2013. The forecasts were highly accurate as much of the region experienced $>25 \mathrm{~cm}$ of snow, with many densely populated areas receiving $>50 \mathrm{~cm}$. Winds gusting to 38 $\mathrm{m} \mathrm{s}^{-1}$ compounded residents' misery, and earned this storm the well-deserved moniker "Blizzard of 2013." Government, schools, and businesses shut down, and most residents spent the subsequent weekend clearing snow before returning to work and school the following week.
Almost exactly 35 yr earlier, a somewhat similar storm struck the region. The meteorological characteristics of this storm (the Northeast Blizzard of 1978, hereafter simply termed the "Blizzard of 1978"), especially those that would have been experienced at the ground, were almost the same as the Blizzard of 2013. However, the societal impacts were quite different. Thousands of motorists were stranded on highways in and around Boston, and Logan International Airport was closed for five days. The entire region was crippled for days, and area schools were closed for more than one week.

Thus, these similar storms had vastly different societal impacts. This paper will begin with a review of the Blizzard of 1978 and a more in-depth case study of the Blizzard of 2013. It will then document the impacts of both storms and end with a discussion of

Corresponding author address: David A. Call, Department of Geography, Ball State University, Muncie, Indiana 47306

E-mail: dacall@bsu.edu 
the differences. Although the Blizzards of 1978 and 2013 were similar meteorologically, the impacts of the 2013 storm were much less severe than for the 1978 storm owing to improved forecasting and a much stronger response by government and individuals prior to the onset of the 2013 storm.

\section{Background and methods}

Case studies in meteorology have a long tradition, and winter storms are no exception (e.g., Hayden 1888; Mook 1956; Bosart 1981; Kocin et al. 1995; Weisman 1996.) One of the most thorough catalogs of snowstorms that specifically affected the Northeast Corridor is Kocin and Uccellini's (2004a) monograph. Of particular interest to this paper is their detailed study of the Blizzard of 1978 (Kocin and Uccellini 2004a, pp. 494-503). Because the Blizzard of 2013 is more recent, more detail about the 2013 storm will be provided in this paper. This study follows similar methods to the previously cited works. For the section examining the meteorology of the storms themselves, similar methods to prior works by Kocin and Uccellini (1990, 2004a) will be used. This involves obtaining observation data and model output from weather archives and systems maintained by the National Oceanic and Atmospheric Administration (NOAA), National Climatic Data Center (NCDC), and other similar sources.

Many case studies of winter storms also include information on impacts. However, detailed scientific examinations of snowstorm impacts are less common. One of the earliest ones is by Rooney (1967). More recent examples include those done by Changnon (1979), Kocin and Uccellini (2004b), and Call (2005). The meteorological similarities of the two storms studied herein provide a good opportunity to examine how these impacts evolved with time, building on prior work by Call $(2005,2010)$.

Call (2005), in particular, identified three broad categories of factors that affect the impact of snowstorms. These include meteorological variations, governmental response, and actions of the general public. The quality and communication of forecasts also affect the impacts of snowstorms (Howe and Cochrane 1976; Call 2005) and, more generally, other disasters (Sorenson 2000; Pielke 2003); for anecdotes relating to a specific recent disaster, see the relevant NWS service assessment. Thus, information relating to the three broad categories of factors and weather forecasting was collected and cataloged. For meteorological variations, data collected included raw observations and public information statements listing snow totals and wind speed and gusts. These allowed for examination of how snow amount, snow intensity, wind, and timing may have impacted society. To assess governmental response and actions of the general public, newspapers were read beginning two days before the storms and ending after there were two days of minimal or no effects reported. This is similar to methods in previous studies of winter weather impacts (Call 2005, 2010). Effects were categorized into groups consisting of the following: travel (auto, plane, mass transit, and pedestrian), power outages, carbon monoxide, schools, businesses, and other. Additionally, relevant issues of NCDC's Storm Data were read and archived news reports (where available) were viewed. To examine how forecasting and dissemination may have played a role, products issued by NWS Boston were catalogued. These include zone forecasts, winter storm watches and warnings, and special weather statements. Finally, references to forecast quality, preparation, or actions taken by the general public also were noted when found in news reports and other accounts.

For the societal impacts examination, the study area was limited to Boston and nearby areas of eastern Massachusetts. Boston experienced some of the greatest disruption from the Blizzard of 1978. In addition, Boston received similar amounts of snowfall and experienced somewhat similar weather conditions with each storm, while other major cities in the region (e.g., Portland, Maine) saw more significant differences in the weather, adding another layer of complexity.

\section{Meteorological comparison}

This section will discuss the weather associated with the two blizzards. Because the Blizzard of 1978 already has been documented in both meteorological and popular literature (Dickson 1978; Tougias 2001; Haraden 2003; Kocin and Uccellini 2004a; Strauss 2008), only a brief review of this storm is provided.

\section{a. The Northeast Blizzard of 1978}

During a several week period just prior to the 1978 blizzard, several other winter storms affected the Northeast United States. These were not reliably predicted by the few operational models or forecasters during a very active winter weather period. In 1978, there were only a handful of numerical weather prediction models, and these showed a significant lack 
of skill predicting winter storms even 1-2 days out (Brown and Olson 1978). Therefore, when forecasters saw the operational forecasts for the 6-7 February blizzard on February 3-5, they were understandably skeptical that any storm would occur in a few days, much less a record-breaking storm.

Surface weather maps only showed a weak low pressure system over the Midwest the day before the storm hit New England, producing a small area of mostly light snow-hardly indicative of a major storm. However, forecasts of an upper-level trough over south-central Canada and the Midwest indicated that the upper trough would intensify or amplify to such an extent that a very strong surface cyclone could develop. In 1978, there was very little confidence that this scenario would actually be a reliable forecast, but it ultimately proved to be correct.

The storm developed rapidly on 6 February, deepening at a rate of $>1 \mathrm{hPa} \mathrm{h}^{-1}$ for $\geq 18 \mathrm{~h}$ as it moved from a position off the Virginia Coast to just south of Long Island, and then moved very slowly during the following $12 \mathrm{~h}$ (Fig. 1). During this period, winds in Boston increased to $13-22 \mathrm{~m} \mathrm{~s}^{-1}$ with gusts as high as $35 \mathrm{~m} \mathrm{~s}^{-1}$ (Cape Cod, Chatham, Massachusetts, reported a gust to $42 \mathrm{~m} \mathrm{~s}^{-1}$ ). Severe coastal flooding occurred as water built up through four successive high tides. A significant amount of snow fell, as shown in Fig. 2. A broad area extending from Baltimore, Maryland, to Portland, Maine, experienced 25-50 cm (10-20 in) of snow, and most of southeastern New England experienced amounts $>50 \mathrm{~cm}$ (20 in). The Northeast Snowfall Impact Scale (NESIS) value for the snowfall distribution was 5.78, which easily placed the Blizzard of 1978 in the "major" category (Kocin and Uccellini 2004a).

\section{b. The New England Blizzard of 2013}

The 8-9 February Blizzard of 2013 also could be considered one of southern and eastern New England's greatest snowstorms. It also was the first significant winter storm in a couple of years for New England, except for an out-of-season storm in October 2011.

\section{1) OBSERVED WEATHER WITH THE BLIZZARD OF 2013}

For much of coastal New England, this was a true blizzard, not only combining snow and wind, but also the older criterion of bitter cold weather (temperatures $\left.<-6^{\circ} \mathrm{C}\right)$. Dire forecasts about the potential impact of the storm were validated by the actual conditions from

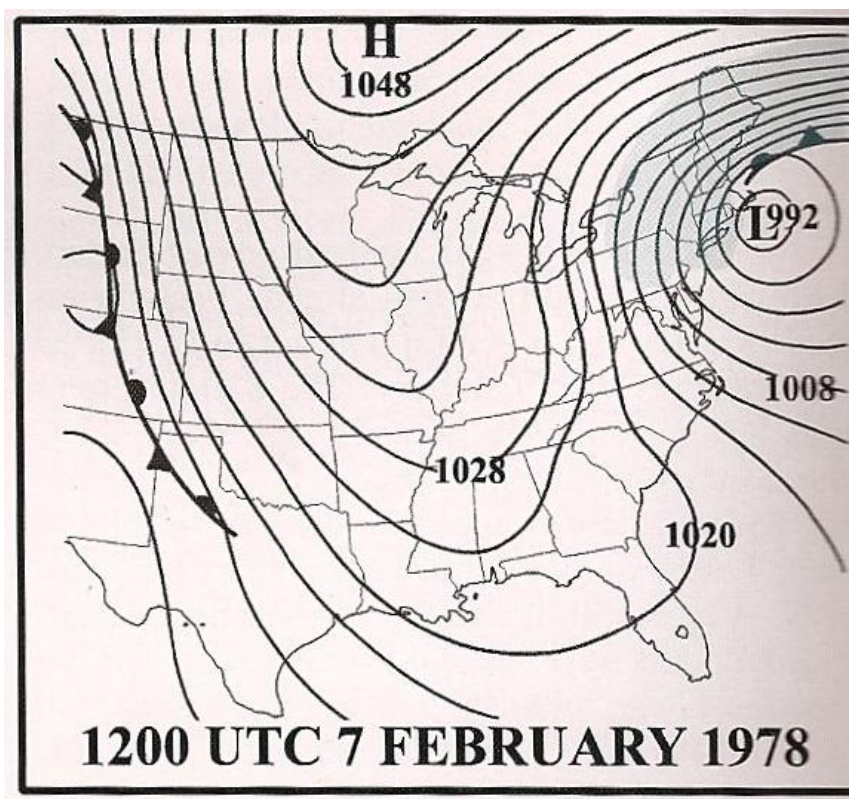

Figure 1. Surface depiction of the Blizzard of 1978 near the time of peak intensity. From Kocin and Uccellini (2004a). Click image for an external version; this applies to all figures hereafter.

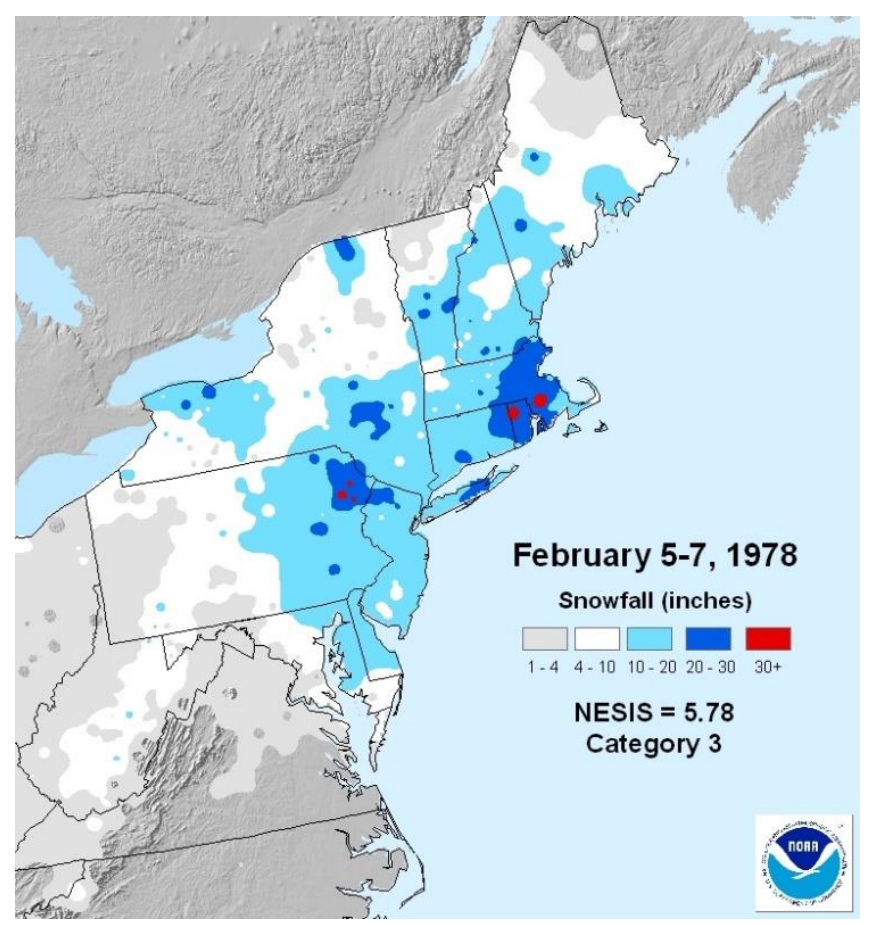

Figure 2. Map showing snowfall the distribution associated with the Blizzard of 1978 (NESIS = 5.78, Category 3). Map courtesy of NOAA.

eastern Long Island and Connecticut across Rhode Island, central and eastern Massachusetts into southeastern New Hampshire, and coastal Maine. The combination of a rapidly deepening cyclone, extreme snowfall rates (up to $18 \mathrm{~cm} \mathrm{~h}^{-1}$ ), hurricane-force wind 
gusts, coastal flooding and erosion, and temperatures that fell to $-7^{\circ} \mathrm{C}$ to $-12^{\circ} \mathrm{C}$ (teens ${ }^{\circ} \mathrm{F}$ ) provided all of the elements for one of the great winter storms.

A significant area with $>76 \mathrm{~cm}$ (30 in) of snow occurred-generally in $<24 \mathrm{~h}$-across east-central Long Island and a good portion of Connecticut, as well as over some areas of Massachusetts, New Hampshire, and Maine (see Fig. 3). The area of $>50 \mathrm{~cm}$ (20 in) of snow was quite extensive, covering much of eastern Long Island, much of Connecticut and Massachusetts (except the far west and southeast), as well as coastal New Hampshire and Maine. All-time 24-h or stormtotal snowfall records were established for the cities of Portland, Maine (80 cm, or 31.9 in), Bridgeport, Connecticut $(76 \mathrm{~cm}$, or $30.0 \mathrm{in})$ and Islip, New York (71 cm, or $27.8 \mathrm{in}$ ). There were several reports of roof collapses due to the weight of the snow. In Boston, the $63 \mathrm{~cm}(24.9 \mathrm{in})$ of snow was the fifth greatest storm total on record; $73 \mathrm{~cm} \mathrm{(28.7} \mathrm{in)} \mathrm{fell} \mathrm{at} \mathrm{Worcester,}$ Massachusetts, where it was third greatest; and the 58 $\mathrm{cm}$ (22.8 in) observed at Bradley Windsor Locks also was third highest. The NESIS value for the snowfall distribution was 4.35 , which placed the storm in the "major" category.

Wind speeds from eastern Long Island across much of coastal New England gusted from $22 \mathrm{~m} \mathrm{~s}^{-1}$ to $>36 \mathrm{~m} \mathrm{~s}^{-1}$. At Nantucket, Massachusetts, winds gusted in excess of $25 \mathrm{~m} \mathrm{~s}^{-1}$ consecutively for $>15 \mathrm{~h}$ with a peak gust of $34 \mathrm{~m} \mathrm{~s}^{-1}$. Boston recorded a similar gust, which is equivalent to hurricane strength. Coastal flooding occurred throughout the usual vulnerable coastal stretch of eastern Massachusetts and also on the islands of Nantucket and Martha's Vineyard, although it occurred over two successive high tides (fewer than the four that occurred within 1978).

\section{2) Meteorology of THE BlizZARD of 2013}

The winter storm that became the Blizzard of February 2013 began with a traditional setup featuring a large cold anticyclone north of the United States/ Canadian border and two separate areas of low pressure. The first of these developed over the Midwest on 6-7 February and triggered a significant snowfall across Wisconsin and Michigan into western New York. The second low pressure, which ultimately became the deep low near New England, developed along the western Gulf Coast on 6 February. It then moved east-northeastward toward the eastern Gulf and then northeastward along the Southeast Coast before rapidly intensifying off the Middle Atlantic Coast.

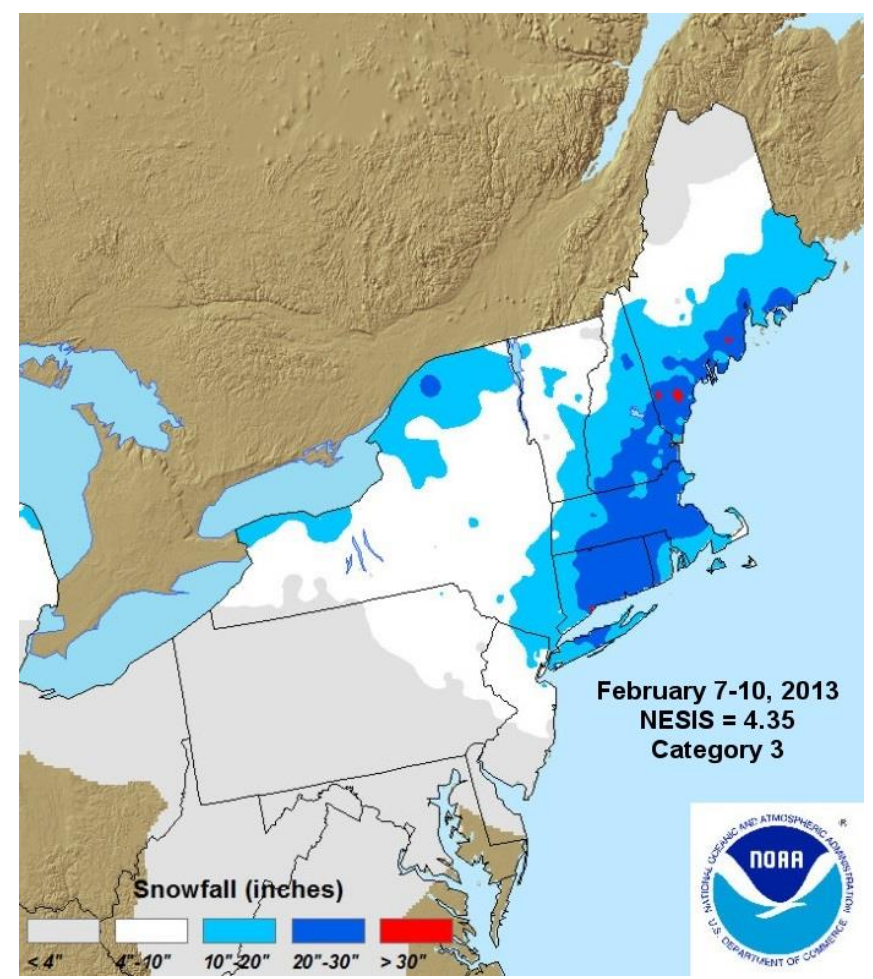

Figure 3. Map showing snowfall distribution associated with the Blizzard of 2013 (NESIS $=4.35$, Category 3 ). Notice the similarity in snowfall amounts in eastern MA with those from 1978 (cf. Fig. 2). Map courtesy of NOAA.

On 8 February, the surface low continued to move northeastward to the east of New Jersey and south of Long Island and New England, where it deepened rapidly. The central pressure of the low fell from 998 $\mathrm{hPa}$ at 1200 UTC 8 February to $979 \mathrm{hPa}$ to the south of southeastern New England by 0000 UTC 9 February - a 19-hPa fall in only 12 h (Fig. 4). During this period, snow expanded northward across northeastern New Jersey and eastern New York into New England. Meanwhile, rain fell across New York City and Long Island. During the afternoon, this rain turned back to snow and intensified. Winds also began to increase dramatically along the coast from New Jersey northeastward across Long Island into much of southern and central New England.

As the snow and winds increased, an exceptionally heavy band of snow developed across east-central Long Island into central Connecticut (Fig. 5). At Islip, New York, snow rates increased to $7.6 \mathrm{~cm} \mathrm{~h}^{-1}$ (3 in $\mathrm{h}^{-1}$ ), and before the night was over, hourly snowfall rates of $10-15 \mathrm{~cm}$ (4-6 in) with isolated instances of $18 \mathrm{~cm} \mathrm{~h}^{-1}\left(7 \mathrm{in} \mathrm{h}^{-1}\right)$ were reported within this band. The snowband was not just confined to Long Island and Connecticut, but also pivoted northward into 


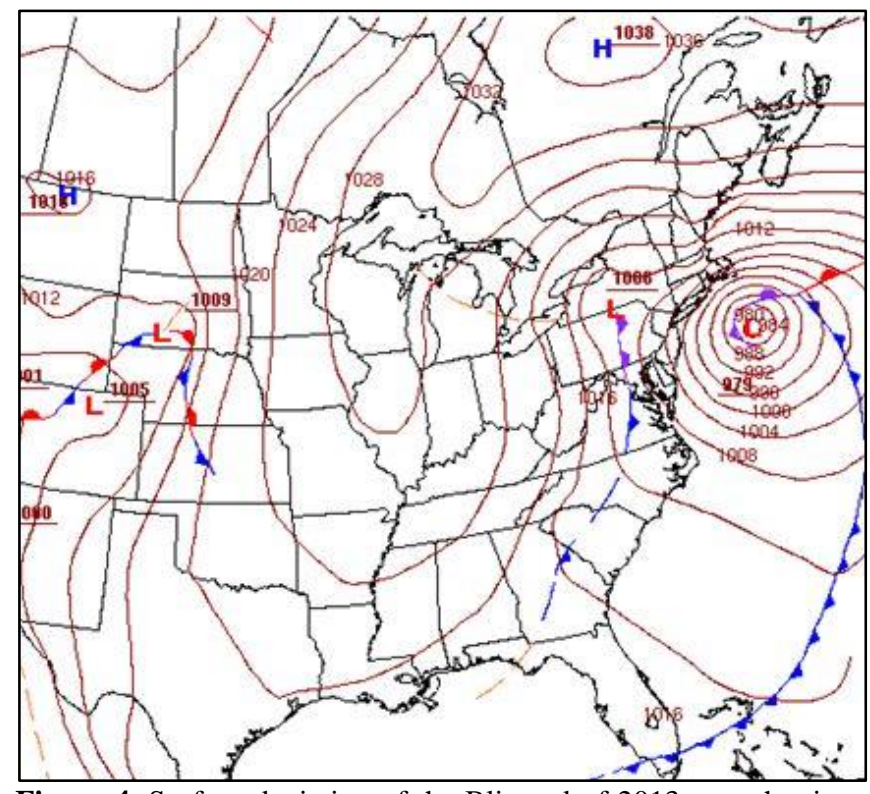

Figure 4. Surface depiction of the Blizzard of 2013 near the time of peak intensity. Notice the similarity of the position and intensity of the surface low with that of 1978 (cf. Fig. 1). Map courtesy of NOAA.

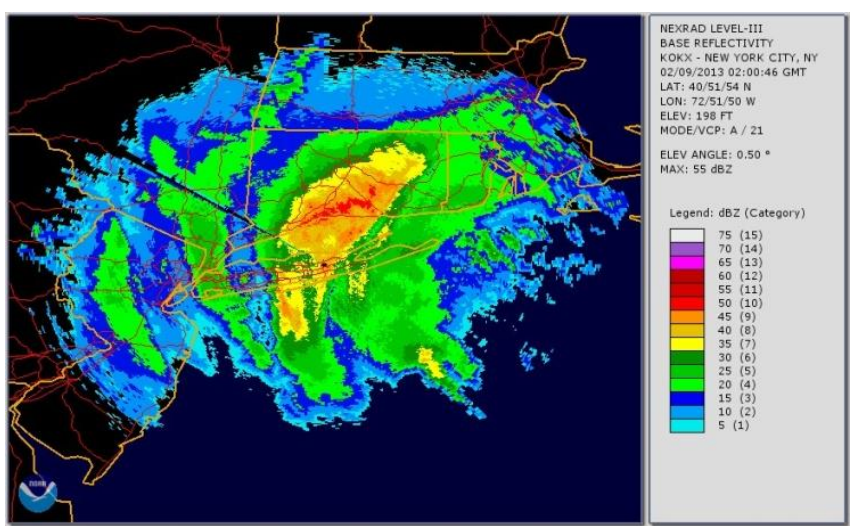

Figure 5. Radar image from Upton, NY (KOKX) at 2100 LT 8 February 2013 (0200 UTC 9 February 2013). Large radar reflectivity values over Long Island, NY, and CT corresponded to snowfall rates of approximately $8-15 \mathrm{~cm} \mathrm{~h}^{-1}\left(3-6 \mathrm{in} \mathrm{h}^{-1}\right)$.

central Massachusetts, southeastern New Hampshire, and coastal Maine, resulting in Portland's greatest snowfall on record. During the evening, the band remained or reformed over the same area, allowing for rapid increases in storm total snowfall.

Over eastern New England, where the heaviest snows had been forecast, snow totals were lighter than those within the heavy snowband farther west, where as much as $102 \mathrm{~cm}$ (40 in) was reported at Hampden, Connecticut. However, in the late overnight and early morning, the band began to move eastward and snowfall rates increased across much of eastern New
England, resulting in the widespread areas of 51-102 $\mathrm{cm}$ (20-40 in) of snow.

During the evening and into the night of the 8th, winds across eastern New England averaged 13-22 m $\mathrm{s}^{-1}$ from a northeasterly direction, gusting to $27-38 \mathrm{~m}$ $\mathrm{s}^{-1}$, reducing visibilities to $<0.4 \mathrm{~km}(0.25 \mathrm{mi})$, and easily meeting one of the criteria for blizzard conditions. Wind gusts reached $34 \mathrm{~m} \mathrm{~s}^{-1}$ at Nantucket, which reported an extended period of rainfall, whereas rain changed to snow several hours earlier at Martha's Vineyard. Temperatures hovered near to just below $0^{\circ} \mathrm{C}$ with the northeasterly winds, but winds soon backed to the north, drawing much colder air southward and dropping temperatures close to $-10^{\circ} \mathrm{C}$.

Between 0000 and 1200 UTC 9 February, the surface low continued to deepen to about $970 \mathrm{hPa}$ and slowed down east of eastern New England. As the heavy snowband began to pivot eastward, snow gradually ended from west to east across New England, but actually increased across eastern New England, with Boston getting $37.6 \mathrm{~cm}$ (14.8 in) on top of the $25.7 \mathrm{~cm}(10.1 \mathrm{in})$ that fell by midnight starting 9 February. Heavy snow extended along the entire stretch of the New England coastline from eastern Massachusetts all the way through eastern Maine. Snow ended in Boston by early afternoon on the 9th and ended later in the day across eastern Maine.

\section{c. A comparison of the 1978 and 2013 storms}

Both snowstorms involved the development of rapidly deepening cyclones that strengthened to peak intensity while moving toward southeastern New England. Both systems slowed in speed as they moved just south of southern New England, reflecting their explosive development as they approached New England, but then they matured and began to fill (weaken) once they passed by New England.

Large pressure gradients between the deepening cyclone and cold anticyclone located to the north of New England helped establish an environment for strong northeasterly winds north of the cyclone center, producing severe coastal flooding across eastern Massachusetts. Wind gusts approached or exceeded hurricane force especially along the eastern and southeastern Massachusetts coastline for both storms.

The storm surge in Boston Harbor for the February 1978 storm $(1.47 \mathrm{~m}$, or $4.82 \mathrm{ft})$ was the highest on record (dating back to 1921). An all-time high water mark of $4.65 \mathrm{~m}(15.25 \mathrm{ft})$ above the mean lower low water was set at the Boston Harbor National Ocean 
Service tide gauge, building over a period including four successive high tides, creating widespread and historic coastal flooding. The storm surge during the

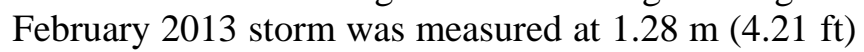
over two consecutive high tides, which still contributed to significant coastal flooding, but because the peak occurred during a low tide, the severity of the flooding was reduced.

In terms of weather experienced at the ground, Table 1 summarizes the weather conditions observed at Boston's Logan Airport. Both storms deposited around $65 \mathrm{~cm}$ of snow over a little more than one day, although snow fell for nine hours longer in 1978 than in 2013. Average wind speeds were within $4 \mathrm{~m} \mathrm{~s}^{-1}$ of each other (higher in 1978) and peak wind gusts were both between 35 and $40 \mathrm{~m} \mathrm{~s}^{-1}$. Therefore, whereas both storms appear similar meteorologically, the February 1978 storm lasted longer, had somewhat stronger winds, had a higher liquid water content (heavy wet snow is denser than dry, fluffy snow in colder storms, making it more difficult to remove), and was associated with more severe coastal flooding. Although these factors likely affected the ability of government and individuals to cope with the storms, the differences alone probably are not sufficient to explain the vast difference in the impacts of the storms.

Table 1. A comparison of the surface weather conditions observed at Boston's Logan Airport during the Blizzards of 1978 and 2013.

\begin{tabular}{|c|c|c|}
\hline & $\mathbf{1 9 7 8}$ & $\mathbf{2 0 1 3}$ \\
\hline Total Snowfall & $68.8 \mathrm{~cm}(27.1 \mathrm{in})$ & $63 \mathrm{~cm}(24.9 \mathrm{in})$ \\
\hline Liquid Water Equivalent & $6.9 \mathrm{~cm}(2.74 \mathrm{in})$ & $4.6 \mathrm{~cm}(1.85 \mathrm{in})$ \\
\hline Snow-to-Liquid Ratio & $10: 1$ & $13: 1$ \\
\hline Duration of Snow & 1 day, $13 \mathrm{~h}$ & 1 day, $4 \mathrm{~h}$ \\
\hline Average Wind Speed & $15.7 \mathrm{~m} \mathrm{~s}^{-1}$ & $12.0 \mathrm{~m} \mathrm{~s}^{-1}$ \\
\hline Peak Wind Gust & $35 \mathrm{~m} \mathrm{~s}^{-1}$ & $38 \mathrm{~m} \mathrm{~s}^{-1}$ \\
\hline Average Temperature & $0^{\circ} \mathrm{C}\left(32^{\circ} \mathrm{F}\right)$ & $-4^{\circ} \mathrm{C}\left(25^{\circ} \mathrm{F}\right)$ \\
\hline
\end{tabular}

\section{Impacts and response}

Whereas both blizzards halted nearly all comercial and other activities in and around Boston, the 1978 storm had impacts that were considerably longer and more wide-ranging, as summarized in Table 2 . This section will elaborate on the differences in impacts and governmental response. Because weather forecasts played a major role in governmental response, a discussion of their role also will be included.
Table 2. A comparison of selected impacts in and around Boston, MA, from the Blizzards of 1978 and 2013. [*Limited service; full restoration took 3 days.]

\begin{tabular}{|c|c|c|}
\hline $\begin{array}{c}\text { Massachusetts Major } \\
\text { Roads and Highways }\end{array}$ & $\begin{array}{c}\text { Motorists } \\
\text { stranded; 3000+ } \\
\text { cars and 500+ } \\
\text { trucks abandoned }\end{array}$ & $\begin{array}{c}\text { Driving ban } \\
\text { issued in advance; } \\
\text { little disruption }\end{array}$ \\
\hline Boston Mass Transit & Down 2 days & Down 1.5 days* \\
\hline Boston Schools & Closed 3 weeks & Closed 2 days \\
\hline Boston Logan Airport & Closed 5 days & Closed 1 day \\
\hline Mail Delivery & $\begin{array}{c}\text { Suspended at } \\
\text { least 3 days }\end{array}$ & Suspended 2 days \\
\hline
\end{tabular}

\section{a. Impacts of the storms}

Both storms crippled the transportation network in and around Boston. In 1978, >3000 cars and >500 trucks were abandoned along Route 128 alone (Strauss 2008), stranding numerous motorists. This was because the onset of the snow was delayed until late morning, and many people had gone about their normal business (mix1041.cbslocal.com/2013/02/ 06/flashback-blizzard-of-78-begins-its-attack-on-newengland/; NWS 2014). In 2013, the traffic disruptions were much smaller. Government offices, schools, and many businesses never opened, owing to forecasts calling for significant snow (Boston Globe, $9 \mathrm{Feb}$ 2013). This was in spite of the fact that the snow did not begin until about 0900 LT 8 February 2013 (add 5 $\mathrm{h}$ to LT to obtain UTC). In 1978, Logan airport shut down at 1915 LT Monday and remained closed for five days (Mathews et al. 1978). Airlines also ceased operation in 2013, with the last flight leaving Logan Airport at 1513 LT 8 February (Boston Globe, 9 Feb 2013), but service was running again the next day (Christian Science Monitor, 8 Feb 2013). Nonetheless, an estimated 5000-6000 flights in total were cancelled by the storm.

Other forms of mass transit closed in both storms, but the closings in 1978 lasted longer. Even though the Massachusetts Bay Transportation Authority (MBTA) technically ran trains until 0200 LT 7 February 1978, drifting snow forced the closure of aboveground lines, and commuter rails closed considerably earlier. The MBTA unsuccessfully attempted to resume operations around 0600 LT 7 February 1978, and eventually announced a halt in operations that would last until 9 February 1978 (Boston Globe, 8 Feb 1978). In 2013, service was halted on Friday, 8 February. Limited service resumed on Sunday afternoon (10 February) with a full schedule anticipated to resume on 11 February (Boston Globe, 11 Feb 2013). 
Both storms caused numerous power outages. In $1978,>100000$ customers in Boston lost power at the height of the storm (Boston Globe, 8 Feb 1978). Surprisingly little news coverage followed, perhaps because other problems were more pressing. In 2013, $>420000$ customers lost power in Massachusetts at the height of the storm (Boston Globe, 13 Feb 2013). Social media posts from news sources and power companies give conflicting numbers, but indicate that most power was restored within a day or two. News media reported that $>90 \%$ of customers had power restored within four days, and all customers had power restored within a week (Boston Globe, 16 Feb 2013). Related to power outages is the issue of carbon monoxide poisoning. Curiously, though, all carbon monoxide deaths were in connection with people in automobiles that were idling. No reports of people suffering from carbon monoxide poisoning in buildings, or in connection with generator use, were reported, even though these have been reported with other winter storms.

In 1978, schools were open on the day that the blizzard began, but they closed early and remained closed for the rest of the week. Most schools did not resume classes until 15 or 16 February; owing to road conditions and a pre-scheduled break, Boston City schools did not resume until 27 February 1978 (Boston Globe, 16 Feb 1978). As a result of the long duration of school closings, many school systems received waivers that exempted them from having to make up all of the days missed. Waivers ranged from one or two days in less hard hit counties to four or even five days in Boston and some other nearby suburbs (Ibid.). In 2013, schools did not open at all on the primary day of the storm (Friday), and the second day of the storm was a Saturday. While many schools remained closed early the following week, most were reopened by 13 February, the first Wednesday after the storm (Boston Globe, 13 Feb 2013).

Finally, a variety of other impacts were reportedranging from slip-and-fall injuries (both storms), looting (1978), suspension of mail delivery (2013), and Catholic parishioners being excused from mass (2013). These impacts also may have occurred with the other storm; it is unclear from news accounts. In 1978, most public agencies were closed for three to five days. Most public welfare offices in Boston opened 12 February 1978 to issue food stamps to needy families. Red Cross service centers opened 12 February as well. Courts and other public agencies were back to normal by 13 February 1978 . Post offices reopened on 10 February and residents were permitted to pick up mail in person if they could get there. This was after widespread difficulty in delivering mail overnight on 9-10 February (Boston Globe, 10 Feb 1978). The Postal Service also curtailed mail delivery for two days in 2013 (Friday/Saturday) according to a press release.

\section{b. Forecasts and government response}

In 1978, scant mention was made of the storm beforehand. Weather bulletins prior to the storm forecasted snow but not a major blizzard. The first blizzard warning was not issued until 4 February at $2300 \mathrm{LT}$, and this only applied to marine interests (Frank 1978). One local forecaster noted that while he was confident in a major snowstorm, he did not expect a "real blizzard" (www.wjla.com/blogs/weather/2013/02/ blizzard-of-78-being-there-17997.html). And as previously mentioned, the state of forecasting such storms in 1978 left forecasters and the public very skeptical (e.g., Brown and Olsen 1978) and reduced confidence in weather forecasters (Christian Science Monitor, 9 Feb 2013). As a result, local authorities did not make unusual or notable preparations prior to the onset of snow on 6 February 1978. Furthermore, when the snow did not begin around sunrise, as originally forecasted, the general public was disinclined to heed forecasts calling for a major snowstorm, and went about their usual business.

The response in 1978 was largely reactionary in nature. Former Governor Michael Dukakis mobilized the 3000-man Massachusetts National Guard and called Federal troops from Ft. Bragg, North Carolina, and Ft. Hood, Texas, on 8 February 1978, which brought an additional 800 men to aid in digging out (Boston Globe, 8 Feb 1978). In total, about 10000 workers-including military personnel flown into Boston from bases in the South-and 3500 pieces of equipment were used to dig out the area (Boston Globe, 9 Feb 1978). Again, however, these resources were used to respond after the snow had fallen, and were not used in advance.

Forecasters in 2013 sounded the alarm earlier and with more authority. As early as 3 February 2013, five days before the storm, NWS forecasters noted the potential for a "significant" winter storm in their area forecast discussions. By 6 February 2013, two days before the storm, forecasters stated that they expected "a potential historic winter storm and blizzard" in their winter storm warning product. This was quite different 
from the lack of confidence two days prior to the 1978 storm. Forecasters also expressed "moderate" confidence in $\geq 15 \mathrm{~cm}$ ( 6 in) of snowfall. The winter storm warning was upgraded to a blizzard warning on the afternoon of 7 February, approximately $18 \mathrm{~h}$ before the first flakes fell at Logan Airport. In an interview for the newspaper on the day of the storm, one NWS meteorologist warned that people not home by Friday afternoon could be "stranded" (Boston Herald, 8 Feb 2013). Behind the scenes, forecasters at the Boston NWS forecast office began emailing briefings to area emergency managers as early as 5 February, and started conference calls on 6 February (J. DelliCarpini 2014, personal communication).

The dire warnings and high confidence expressed by forecasters motivated an early and aggressive reaction by the public sector and individual citizens. As early as 7 February, the Massachusetts Department of Transportation reassured citizens that it had a fleet of $>4000$ public and private vehicles that could be mobilized within 75 min (Boston Herald, 7 Feb 2013). When asked about the credibility of the forecasts, the spokesman said, "We're certainly not going to call the bluff of any of the meteorologists" (Ibid.). Massachusetts Governor Deval Patrick declared a state of emergency at 1200 LT 8 February (Lowell Sun, 9 Feb 2013) and banned most vehicles from roads after 1600 LT 8 February (Christian Science Monitor, 9 Feb 2013). This was the first travel ban issued since the Blizzard of 1978, but that ban was issued during the second day of the storm instead of prior to the storm. Thousands of National Guard troops also were mobilized in Massachusetts (Boston Globe, 8 Feb 2013); again, this occurred pre-storm as opposed to post-storm. At a local level, town and city governments prepared equipment and workers to clear the road before the first flake fell. In Boston, officials announced plans to mobilize $>200$ plows and salt spreaders before dawn on Friday and expand the workforce to 400 workers by 0900 LT (Boston Globe, 8 Feb 2013); and as noted earlier, the Massachusetts Department of Transportation had their crews at the ready. Most schools simply were closed on 8 February rather than trying to open. Transportation interests also acted in advance. Airlines cancelled flights, utilities prepositioned resources to aid in electricity restoration, and the MBTA announced plans to cut public transportation services in half; all of these actions occurred in advance of the storm (Boston Globe, 8 Feb 2013).
Government officials warned individual citizens with one consistent message. Mayor Menino urged motorists not to drive into the City of Boston because of a "serious storm" (Christian Science Monitor, 8 Feb 2013) and told people to just stay home. Governor Patrick declared a state of emergency and issued a travel ban because of expected "extremely dangerous conditions" (Boston Globe, 8 Feb 2013). He also ordered the mass transit system shut down at $1530 \mathrm{LT}$ the day of the storm and warned that all travel would be "nearly impossible" (Boston Herald, 8 Feb 2013).

Forecasts in 2013 were perceived as more reliable by officials and the general public than in 1978, and this contributed to the difference in response. In recalling the 35th anniversary of the 1978 storm, a Boston television reporter noted that at that time, "some people clearly didn't trust" the forecasts. This point was echoed by Matt Bowling, owner of a Blizzard of 1978 website, who noted that people had been "trained to not pay much attention to the weathermen" (Christian Science Monitor, 9 Feb 2013). In contrast, in 2013, a Boston Globe article quoted a local resident as noting that, while forecasters have had a lot of misses, this storm was "going to be bad" (9 Feb 2013). In 1978, when the onset of the storm was delayed until mid-morning, people went about their business of going to work and school. In 2013, the storm also did not begin until after the morning rush hour (0905 LT according to the observations), but government, schools, and businesses did not open. In addition, in 2013 the general public engaged in a "mad rush" (Call 2005) prior to the storm in which they mobbed stores for basic supplies (Boston Globe, 8 Feb 2013). No such rush was reported in 1978. Finally, the government response in 1978 was reactive, while in 2013 it was proactive. When commenting on Governor Deval Patrick's preemptive driving ban in 2013, former Governor Michael Dukakis noted that he would have banned traffic sooner in 1978 "if the forecasting had been more accurate" (Boston Globe, 9 Feb 2013). All of these observations suggest that people were willing to accept the forecasts as being correct and reliable in 2013.

Memories of the Blizzard of 1978 influenced the response to warnings. Newspaper articles made reference to officials wanting to avoid the "mayhem" of 1978 (London Sunday Times, 8 Feb 2013). Local citizens expressed concern about the 2013 storm by referencing 1978; one citizen in particular hoped that conditions "would not be as bad as 1978" (Boston Globe, 9 Feb 2013). Other reports marking the 35th 
anniversary of the Blizzard of 1978, written just a few days prior to the 2013 storm, reminded people of the institutional failures (mix1041.cbslocal.com/2013/02/06/ flashback-blizzard-of-78-begins-its-attack-on-new-england). Following the storm, news articles compared the 2013 response to that of 1978 (Boston Globe and Boston Herald, 9 Feb 2013). Despite the fact that new governmental leadership was in place, and, of course, many residents had come and gone since 1978, the numerous media references influenced the collective memory of officials and ordinary citizens and reflected a societal memory of the prior disaster. ${ }^{1}$

\section{Conclusion}

In conclusion, the Blizzards of 1978 and 2013 were similar synoptic snowstorms that affected Massachusetts. Both storms deposited approximately 51-76 $\mathrm{cm}(20-30$ in) of snow in and around Boston, and both rated as a NESIS Category 3. Both storms had winds that gusted above hurricane force, and both caused coastal flooding. While these conditions appear very similar, the 1978 storm lasted longer than the 2013 storm, the 1978 storm also had somewhat higher winds (at least in Boston), the snowfall in 1978 was heavier and wetter (lower snow-to-liquid ratio), and 1978 had more severe coastal impacts (cf. Table 1).

However, these differences alone cannot fully explain why the impacts of the storms were quite different. While disruptive, the Blizzard of 2013 only crippled the region for three days, and two of those days were the weekend following it. This was a dramatically different story from 1978, when roads were clogged with cars for days. The National Guard had to rescue numerous people and dig out stuck vehicles, and students missed school for as long as three weeks. Why were the effects so different?

The most significant difference was the weather forecasting and reaction to it by the public, media, and government. The Blizzard of 1978 developed in an era when forecasting snowstorms was much more challenging than it is today. As described by Brown and Olson (1978), a three-day forecast of the storm was

\footnotetext{
1 J. DelliCarpini from NWS Boston suggested that the "Traffic Nightmare Storm" of 13 December 2007, when numerous commuters were stranded for hours on area roadways, may have influenced collective memory as well. Unfortunately, we found no direct evidence to support this idea. Nonetheless, it seems plausible that some of the leaders and officials involved in the 2007 debacle were in similar roles in 2013, and that their prior experience influenced their 2013 response.
}

considered "the very best possible with the current models of the era." Today it has become almost routine that significant snowstorms are expected three days in advance (though there still are many forecast challenges about the details), and it is not uncommon to foresee significant snow events by as many as five days (e.g., the March 1993 Superstorm) or even eight days in advance (e.g., some forecasts for the 5-6 February and the 9-10 February 2010 mid-Atlantic snowstorms were referred to as "Snowmageddon/ Snowpocalypse"). In the case of the Blizzard of 2013, forecasters began publicly discussing the potential five days in advance and issued the first warnings more than two days beforehand. Almost a full day before the precipitation began, blizzard warnings outlined the potential for serious impacts and recommended that people stay indoors.

Owing to the early warnings and level of confidence expressed by forecasters, the state and local public officials initiated aggressive preparations such as travel bans and telling workers to stay home. They also spoke with a consistent voice in warning citizens of serious consequences. School and business leaders followed suit by requiring or encouraging students and workers to stay home, and members of the general public heeded the warnings. In addition, a collective belief in the credibility and reliability of the forecasts greatly aided the overall response. Government officials and residents prepared, and people stayed home the morning of the storm, even though the snow did not begin until mid-morning.

The multiple references in public officials' and residents' comments suggested that society's collective memory of the Blizzard of 1978 influenced response. Officials did not want to repeat such dubious history, and individuals did not want to be trapped, unprepared, for a long period. Ironically, then, memories of the crippling disaster that resulted from the Blizzard of 1978 caused officials and residents to take actions that prevented 2013 from being a similar disaster. To end, although the Blizzards of 1978 and 2013 were somewhat similar storms meteorologically, improved forecasting and the many preparatory actions taken by government and individuals caused the impacts of the Blizzard of 2013 to be much less significant.

Acknowledgments. The authors thank the Indiana Space Grant Consortium and Ball State University for supporting this research. We also thank the reviewers of this article for their insights; the final draft was a substantial improvement. Finally, the lead author recognizes his late grandfather, 
William, and father, Tom, for collecting several issues of the Boston Globe about the Blizzard of 1978. These articles helped inspire this paper.

\section{REFERENCES}

Bosart, L. F., 1981: The Presidents' Day snowstorm of 1819 February 1979: A subsynoptic-scale event. Mon. Wea. Rev., 109, 1542-1566, CrossRef.

Brown, H. E., and D. A. Olson, 1978: Performance of NMC in forecasting a record-breaking winter storm, 6-7 February 1978. Bull. Amer. Meteor. Soc., 59, 562-575, CrossRef.

Call, D. A., 2005: Rethinking snowstorms as snow events: A regional case study from Upstate New York. Bull. Amer. Meteor. Soc., 86, 1783-1793, CrossRef. , 2010: Changes in ice storm impacts over time: 1886-2000. Wea. Climate Soc., 2, 23-35, CrossRef.

Changnon, S. A., Jr., 1979: How a severe winter impacts on individuals. Bull. Amer. Meteor. Soc., 60, 110-114, CrossRef.

Dickson, R. R., 1978: Weather and circulation of February 1978. Mon. Wea. Rev., 106, 746-751, CrossRef.

Frank, R. A., 1978: Northeast blizzard of '78. DOC/NOAA, Natural Disaster Survey Report 78-1, 66 pp. [Available online at www.nws.noaa.gov/om/assessments/pdfs/ Northeast\%20Blizzard\%20of\%201978.pdf.]

Haraden, C. J., 2003: Storm of the Century: New England's Great Blizzard of 1978. Times Square Books, 144 pp.

Hayden, E., 1888: The Great Storm off the Atlantic Coast of the United States March 11-14, 1888. Nautical Monogr., No. 5, U.S. Government Printing Office, 65 pp.

Howe, C. W., and H. C. Cochrane, 1976: A decision model for adjusting to natural hazard events with application to urban snow storms. Rev. Econ. Stat., 58 (1), 50-58, CrossRef.

Kocin, P. J. and L. W. Uccellini, 1990: Snowstorms along the Northeastern Coast of the United States: 1955 to 1985. Meteor. Monogr., No. 44, Amer. Meteor. Soc., $280 \mathrm{pp}$. , and __, 2004a: Northeast Snowstorms. Vols. 1 and 2, Meteor. Monogr., No. 54, Amer. Meteor. Soc., 818 pp.

, and __, 2004b: A snowfall impact scale derived from Northeast storm snowfall distributions. Bull. Amer. Meteor. Soc., 85, 177-194, CrossRef.

P. N. Schumacher, R. F. Morales Jr., and L. W. Uccellini, 1995: Overview of the 12-14 March 1993 superstorm. Bull. Amer. Meteor. Soc., 76, 165-182, CrossRef.

Mathews, T., M. Phyllis, S. Seidel, and M. Whitaker, 1978: The blitz in Boston. Newsweek, 20 February.
Mook, C. P., 1956: The 'Knickerbocker" snowstorm of January 1922 at Washington, D.C. Weatherwise, 9, 188-191.

NWS, cited 2014: The blizzard of '78...revisited. NWS Taunton, MA, 54 pp. [Available online at www.erh.noaa.gov/box/papers/Bliz78NWS.pdf.]

Pielke, R. A., Jr., 2003: Reducing Vulnerability. Hurricane! Coping with Disaster: Progress and Challenges Since Galveston, 1900, R. Simpson, R. Anthes, M. Garstang and J. Simpson, Eds., Amer. Geophys. Union, 165-173.

Rooney, J. F., Jr., 1967: The urban snow hazard in the United States: An appraisal of disruption. Geogr. Rev., 57, 538-559, CrossRef.

Sorensen, J., 2000: Hazard warning systems: Review of 20 years of progress. Nat. Hazards Rev. 1 (2), 119-125, CrossRef.

Strauss, N., cited 2014: The great Northeast blizzard of 1978 remembered 30 years later in southern New England. [Available online at www.erh.noaa.gov/ box/papers/blizzard78/mainblizzardof78.htm.]

Tougias, M. J., 2001: The Blizzard of '78. On Cape Publications, $128 \mathrm{pp}$.

Weisman, R. A., 1996: The Fargo snowstorm of 6-8 January 1989. Wea. Forecasting, 11, 198-215, CrossRef. 